\title{
Regulatory peptide receptors in human hepatocellular carcinomas
}

\author{
J C Reubi, A Zimmermann, S Jonas, B Waser, P Neuhaus, U Läderach, B Wiedenmann
}

Institute of Pathology, University of Berne Berne, Switzerland J C Reubi

A Zimmermann

B Waser

U Läderach

Department of Surgery, Humboldt University, Berlin, Germany

$S$ Jonas

P Neuhaus

Department of Internal Medicine, Humboldt University, Berlin, Germany B Wiedenmann

Correspondence to: Dr J C Reubi, Division of Cell Biology and Experimental Cancer Research, Institute of Pathology, University of Berne, Murtenstrasse 31, PO Box 62, CH-3010 Berne, Switzerland

Accepted for publication 11 May 1999

\begin{abstract}
Background-Overexpression of regulatory peptide receptors in selected human tumours is of diagnostic and therapeutic relevance.

Aims-To evaluate the expression of somatostatin, vasoactive intestinal peptide (VIP), substance P, cholecystokinin (CCK) $A$ and $B$, and neurotensin receptors in hepatocellular carcinoma (HCC).

Methods-In vitro receptor autoradiography for the various peptide receptors using selective iodinated radioligands on tissue sections in 59 cases of HCC.

Results- $41 \%$ of HCC expressed somatostatin receptors; $47 \%$ expressed VIP receptors. VIP receptors were always identified in non-neoplastic liver tissue. Substance $P$ receptors were only identified in $5 \%$ of HCC but in the majority of their peritumorous and intratumorous vessels. CCK-A and $-B$ and neurotensin receptors were not detected in HCC. The somatostatin receptors showed high affinity for somatostatin and octreotide. The VIP receptors had high affinity for VIP, pituitary adenylate cyclase activating peptide (PACAP) 27, and a VIP1 selective analogue, suggesting the presence of VIP1/ PACAP II type receptors. PACAP I receptors were identified in two cases. Substance $P$ receptors were all of the NK1 subtype. The density of somatostatin receptors in HCC was low compared with the density found in liver metastases of neuroendocrine tumours. The VIP receptor density was always lower in HCC than in adjacent liver tissue.

Conclusions-Somatostatin, VIP, and substance $\mathbf{P}$ may have a receptor mediated role in HCC. Substance $P$ receptors may be involved in regulation of tumour associated blood flow; somatostatin receptors and VIP receptors may mediate tumour growth. Diagnostic and therapeutic evaluation of somatostatin and VIP analogues may be of interest in receptor positive HCC.

(Gut 1999;45:766-774)
\end{abstract}

Keywords: somatostatin receptors; vasoactive intestinal peptide receptors; substance P receptors; receptor autoradiography; tumour vasculature

Several human tumours overexpress receptors for small regulatory peptides, ${ }^{1}$ an observation which has led to a number of clinical applications in the diagnosis ${ }^{2}$ and treatment of tumours. ${ }^{3}$ In vitro investigations have shown, for instance, that somatostatin receptors are expressed by most neuroendocrine tumours ${ }^{4}$; vasoactive intestinal polypeptide (VIP) receptors are expressed by most epithelial tumours ${ }^{5}$; cholecystokinin B (CCK-B)/gastrin receptors are present in medullary thyroid carcinomas, small cell lung cancers, and some gastrointestinal cancers ${ }^{6}$; substance $\mathrm{P}$ receptors are present in brain tumours, medullary thyroid cancers, and breast tumours ${ }^{7}$; and neurotensin receptors are found in meningiomas and ductal pancreatic cancers. ${ }^{89}$

The high incidence and high density of somatostatin receptors in neuroendocrine tumours has led to the development of in vivo somatostatin receptor scintigraphy which allows localisation of small somatostatin receptor positive tumours as well as their metastases in the patient. ${ }^{2}$ Preliminary studies have evaluated the possibility of treating such tumours with yttrium-90 labelled somatostatin analogues. ${ }^{3}$ Furthermore, the use of non-radioactive somatostatin analogues as long term therapy has successfully permitted treatment of the symptoms produced by the overproduction of hormones in these neuroendocrine tumours, as they are massively inhibited by somatostatin analogues. ${ }^{10}$ VIP is emerging as the second peptide of interest as in vivo VIP receptor scintigraphy has been reported to be a useful method for the visualisation of VIP receptor expressing gastrointestinal tumours. ${ }^{11}$ Promising data were also reported for CCK-B receptor expressing medullary thyroid carcinomas. ${ }^{12}$

The expression of regulatory peptide receptors has not yet been studied in hepatocellular carcinoma (HCC), despite the fact that this tumour is the most common primary liver tumour ${ }^{13}$ and that there is no adequate therapy for larger and metastasising tumours. Although recent reports have suggested a possible neuroendocrine component to $\mathrm{HCC},{ }^{14}$ studies on peptide hormones and their receptors have been lacking in this tumour type. However, it has recently been shown by Kouroumalis et al that patients with HCC treated with octreotide survived longer than patients who had not. ${ }^{15}$

The aim of this study was, therefore, to characterise in a large number of HCC the receptor status for a number of regulatory peptides including somatostatin, VIP, substance P, gastrin, $\mathrm{CCK}$, and neurotensin using in vitro

Abbreviations used in this paper: BSA, bovine serum albumin; CCK, cholecystokinin; HCC, hepatocellular carcinoma; ${ }^{125} \mathrm{I}-\mathrm{BHSP}$, Bolton-Hunter substance P; [LTT]-SS-28, [Leu $\left.{ }^{8}, \mathrm{D}-\mathrm{Trp}^{22}, \mathrm{Tyr}^{25}\right]-$ somatostatin 28; NK, neurokinin; PACAP, pituitary adenylate cyclase activating peptide; VIP, vasoactive intestinal peptide. 
Table 1 Histopathological and receptor characteristics of 59 hepatocellular carcinomas, two liver adenomas, and two liver samples

\begin{tabular}{|c|c|c|c|c|c|}
\hline Code & Age/sex & Histopathology & $S S-R^{\star \star}$ & $V I P / P A C A P-R+\dagger$ & $S P-R$ \\
\hline 46 & $39 / \mathrm{M}$ & HCC; trabecular; G1 & - & $+(2787)^{\star}$ & - \\
\hline 11 & $62 / \mathrm{M}$ & HCC; trabecular; solid; G1 & - & $+(2039)^{\star}$ & $-(\mathrm{v}+)$ \\
\hline 17 & $45 / \mathrm{F}$ & HCC; trabecular; solid; G1 & $+(364)$ & $+(7575)^{\star}$ & - \\
\hline 49 & $31 / \mathrm{M}$ & HCC; fibrolamellar; G1 & - & $+(734) \S$ & $-(\mathrm{v}+)$ \\
\hline 52 & $26 / \mathrm{F}$ & HCC; fibrolamellar; G1 & $+(142)$ & $+(928)^{\star}$ & $+(\mathrm{v}+)$ \\
\hline 74 & $21 / \mathrm{F}$ & HCC; fibrolamellar; G1 & - & - & $-(\mathrm{v}+)$ \\
\hline 42 & $67 / \mathrm{M}$ & HCC; pseudoglandular; G1/G2 & - & - & - \\
\hline 15 & $77 / \mathrm{F}$ & HCC; trabecular; G1/G2 & $+(348)$ & - & $-(\mathrm{v}+)$ \\
\hline 62 & $72 / \mathrm{M}$ & HCC; trabecular; G1/G2 & - & $+(728)^{\star}$ & $-(\mathrm{v}+)$ \\
\hline 66 & $58 / \mathrm{M}$ & HCC; trabecular; G1/G3 & $+(341) \mathrm{ht}$ & - & $-(\mathrm{v}+)$ \\
\hline 3 & $69 / \mathrm{M}$ & HCC; pseudogland; G2 & - & $+(1144)^{\star}$ & $-(\mathrm{v}+)$ \\
\hline 28 & $66 / M$ & HCC; pseudoglandular, trabecular; G2 & $+(281)$ & $+(901) \mathrm{ht}^{\star}$ & $-(v+)$ \\
\hline 30 & $35 / \mathrm{M}$ & HCC; pseudoglandular, trabecular; G2 & $+(3490)$ & - & $-(\mathrm{v}+)$ \\
\hline 47 & $74 / \mathrm{F}$ & HCC; pseudoglandular, trabecular; G2 & - & - & $-(\mathrm{v}+)$ \\
\hline 63 & $70 / \mathrm{F}$ & HCC; pseudoglandular, trabecular; G2 & - & $+/-(3972)^{\star}$ & $-(v+)$ \\
\hline 64 & $69 / \mathrm{M}$ & HCC; pseudoglandular, trabecular; G2 & - & $+(1613)^{\star}$ & $-(\mathrm{v}+)$ \\
\hline 21 & $68 / \mathrm{M}$ & HCC; trabecular; G2 & - & $+(1934)^{\star}$ & $-(v+)$ \\
\hline 22 & $68 / \mathrm{F}$ & HCC; trabecular; G2 & - & - & - \\
\hline 24 & $57 / \mathrm{F}$ & HCC; trabecular; G2 & $+(196)$ & $+(3518) \dagger$ & $-(\mathrm{v}+)$ \\
\hline 27 & $64 / \mathrm{M}$ & HCC; trabecular; G2 & - & - & $-(\mathrm{v}+)$ \\
\hline 31 & $70 / \mathrm{M}$ & HCC; trabecular; G2 & - & $+(667) \S$ & $-(\mathrm{v}+)$ \\
\hline 45 & $43 / \mathrm{M}$ & HCC; trabecular; G2 & $+(630)$ & $+(735)^{\star}$ & $-(\mathrm{v}+)$ \\
\hline 57 & $55 / \mathrm{M}$ & HCC; trabecular; G2 & - & - & - \\
\hline 69 & $74 / \mathrm{M}$ & HCC; trabecular; G2 & - & - & - \\
\hline 75 & $60 / \mathrm{M}$ & HCC; trabecular; G2 & - & $+(785) \mathrm{ht}^{\star}$ & - \\
\hline 8 & $48 / \mathrm{F}$ & HCC; trabecular, solid; G2 & - & - & - \\
\hline 14 & $71 / \mathrm{F}$ & HCC; trabecular, solid; G2 & $+(314)$ & $+(5085) \mathrm{ht} /$ liver $+(10312)^{\star}$ & $+(v+)$ \\
\hline 12 & $75 / \mathrm{M}$ & HCC; solid; G2 & - & $+(1186)^{\star}$ & $-(\mathrm{v}+)$ \\
\hline 20 & $36 / \mathrm{F}$ & HCC; solid; G2 & - & $+(329) \S$ & $-(\mathrm{v}+)$ \\
\hline 72 & $66 / \mathrm{F}$ & HCC; solid; G2 & $+(176)$ & $+(471) \S$ & $-(\mathrm{v}+)$ \\
\hline 18 & $35 / \mathrm{M}$ & HCC; fibrolamellar; G2 & - & $+\ddagger$ & $-(\mathrm{v}+)$ \\
\hline 6 & $68 / \mathrm{M}$ & HCC; trabecular; G2/G3 & $+(1702) \mathrm{ht}(\mathrm{G} 3-, \mathrm{G} 2+/-)$ & $+(4872) \mathrm{hm}^{\star}$ & $-(\mathrm{v}+)$ \\
\hline 58 & $63 / \mathrm{M}$ & HCC; trabecular, sclerosing; G2/G3 & - & - & $-(\mathrm{v}+)$ \\
\hline 53 & $62 / \mathrm{M}$ & HCC; solid; G2/G3 & - & $+(646) \S$ & $-(\mathrm{v}+)$ \\
\hline 70 & $48 / \mathrm{M}$ & HCC; solid; G2/G3 & $+(394)$ & - & $-(\mathrm{v}+)$ \\
\hline 10 & $72 / \mathrm{M}$ & HCC; pseudoglandular, trabecular; G3 & $+(258)$ & $+(1537) /$ liver $+(8313)^{\star}$ & $-(\mathrm{v}+)$ \\
\hline 19 & $76 / \mathrm{M}$ & HCC; pseudoglandular, trabecular; G3 & - & - & - \\
\hline 23 & $67 / \mathrm{F}$ & HCC; trabecular; G3 & $+(949)$ & - & - \\
\hline 39 & $75 / \mathrm{M}$ & HCC; trabecular; G3 & - & - & $-(\mathrm{v}+)$ \\
\hline 43 & $68 / \mathrm{M}$ & HCC; trabecular; G3 & $+(364)$ & - & $-(\mathrm{v}+)$ \\
\hline 67 & $59 / \mathrm{M}$ & HCC; trabecular; G3 & $+(2825)$ & - & $-(\mathrm{v}+)$ \\
\hline 71 & $72 / \mathrm{F}$ & HCC; trabecular; G3 & - & $+(1250)^{\star}$ & - \\
\hline 2 & $47 / \mathrm{M}$ & HCC; trabecular, solid; G3 & - & - & $-(\mathrm{v}+)$ \\
\hline 7 & $56 / M$ & HCC; trabecular, solid; G3 & - & - & - \\
\hline 25 & $50 / \mathrm{F}$ & HCC; trabecular, solid; G3 & $+(144)$ & - & $+(\mathrm{v}+)$ \\
\hline 13 & $56 / \mathrm{M}$ & HCC; solid; G3 & $+(310)$ & $+(685) /$ liver $+(12691)^{\star}$ & $-(\mathrm{v}+)$ \\
\hline 29 & $67 / \mathrm{M}$ & HCC; solid; G3 & - & $+(291)^{\star}$ & $-(\mathrm{v}+)$ \\
\hline 34 & $75 / \mathrm{F}$ & HCC; solid; G3 & $+(2787) \mathrm{ht}$ & $+(293) /$ liver $+(7466)^{\star}$ & $-(v+)$ \\
\hline 37 & $56 / \mathrm{M}$ & HCC; solid; G3 & $+(1442)$ & - & $-(\mathrm{v}+)$ \\
\hline 44 & $67 / \mathrm{F}$ & HCC: solid; G3 & - & - & $-(\mathrm{v}+)$ \\
\hline 48 & $72 / \mathrm{M}$ & HCC; solid; G3 & $+(369)$ & - & $-(\mathrm{v}+)$ \\
\hline 59 & $56 / \mathrm{F}$ & HCC; solid; G3 & - & - & $-(\mathrm{v}+)$ \\
\hline 60 & $66 / M$ & HCC; solid; G3 & $+(3622)$ & - & $-(\mathrm{v}+)$ \\
\hline 65 & $61 / M$ & HCC; solid; G3 & - & - & - \\
\hline 68 & $79 / \mathrm{M}$ & HCC; solid; G3 & - & $+(1093)^{\star}$ & $-(\mathrm{v}+)$ \\
\hline 73 & $79 / \mathrm{M}$ & HCC; solid; G3 & $+(130)$ & $+(319)^{\star}$ & $-(v+)$ \\
\hline 26 & $65 / M$ & HCC; solid; G4 & - & - & - \\
\hline 35 & $55 / \mathrm{F}$ & HCC; solid; G4 & $+(184) \mathrm{ht}$ & - & - \\
\hline 1 & $41 / \mathrm{F}$ & HCC; anaplastic; G4 & - & - & $-(\mathrm{v}+)$ \\
\hline 33 & $33 / \mathrm{M}$ & Liver adenoma & - & - & $-(\mathrm{v}+)$ \\
\hline 51 & $54 / \mathrm{M}$ & Liver adenoma & - & $+(6899)^{\star}$ & $-(\mathrm{v}+)$ \\
\hline 32 & $46 / \mathrm{F}$ & Liver & - & $+(8183)^{\star}$ & $-(v+)$ \\
\hline 38 & $72 / \mathrm{M}$ & Liver & - & $+(5312)^{\star}$ & $-(\mathrm{v}+)$ \\
\hline
\end{tabular}

*Vasoactive intestinal peptide (VIP)/pituitary adenylate cyclase activating peptide (PACAP) II receptors identified as VIP1/PACAP II subtype (with high affinity for VIP1 selective analogue).

+VIP1/PACAP II receptors and PACAP I receptors.

$\ddagger$ No VIP/PACAP II receptors but PACAP I receptors.

\VIP/PACAP II receptors without VIP1/VIP2 subtyping.

I: + pseudoglandular part; - trabecular part.

${ }^{\star \star}$ In parentheses: density of ${ }^{125} \mathrm{I}-\mathrm{Tyr}^{3}$-octreotide binding sites (dpm/mg tissue).

††In parentheses: density of ${ }^{125} \mathrm{I}-\mathrm{VIP}$ binding sites (dpm/mg tissue).

ht, heterogeneous receptor distribution; hm, homogeneous receptor distribution; $v+$, receptor positive vessels; HCC, hepatocellular carcinoma.

receptor autoradiography of tissue sections from frozen tumour samples. The results should permit evaluation of the pathophysiological role of the various peptides and peptide receptors in this type of tumour, and identification of potential clinical applications for these peptides.

\section{Material and methods}

\section{MATERIALS}

Aliquots of surgically resected tumours, or of biopsy specimens submitted for diagnostic histopathology were collected from the Univer- sity of Berlin. In total, $59 \mathrm{HCC}$ as well as two hepatic adenomas were included in this study (table 1). The diagnoses were reviewed and formulated according to the guidelines issued by the World Health Organisation. ${ }^{16}$ Tumour grading was based on a four grade procedure. ${ }^{17}$ In addition, liver metastases from neuroendocrine tumours $(n=18)$, including adjacent liver in six cases, were included as control tissues for somatostatin or VIP receptor autoradiography.

All tissues were frozen in liquid nitrogen immediately after surgical resection and stored 
Table 2 Density of somatostatin and vasoactive intestinal peptide (VIP) receptors in hepatocellular carcinoma (HCC)

\begin{tabular}{llll}
\hline & \multicolumn{3}{l}{ Receptor density (dpm/mg tissue) } \\
\cline { 2 - 4 } Tissue & Mean & Median & Range \\
\hline Somatostatin receptors & & & \\
HCC ( $=24)$ & 906 & 356 & $130-3622^{\star}$ \\
Liver metastases of neuroendocrine tumours (n=18) & 3969 & 3547 & $811-10057$ \\
VIP receptors & 1718 & 1010 & $291-7575 \dagger$ \\
HCC ( $=28)$ & 8712 & 8248 & $5312-12691$ \\
Liver $(\mathrm{n}=6)$ & & & \\
\hline
\end{tabular}

${ }^{\star}$ HCC compared with neuroendocrine tumours: $\mathrm{p}<0.0002$ (Mann-Whitney, two tailed). †HCC compared with liver: $\mathrm{p}<0.0001$ (Mann-Whitney, two tailed).

at $-70^{\circ} \mathrm{C}$. Receptor autoradiography was performed on 10 and $20 \mu \mathrm{m}$ thick cryostat (Leitz 1720, Rockleigh, New Jersey, USA) sections of the tissue samples, mounted on microscope slides, and then stored at $-20^{\circ} \mathrm{C}$ for at least three days to improve adhesion of the tis- sue to the slide, as previously described. ${ }^{4}$ Adjacent sections stained with haematoxylin and eosin were used to classify the tumours.

SOMATOSTATIN RECEPTOR AUTORADIOGRAPHY

The radioligands used were the somatostatin analogues ${ }^{125} \mathrm{I}-\left[\mathrm{Tyr}^{3}\right]$-octreotide and ${ }^{125} \mathrm{I}-$ $\left[\mathrm{Leu}^{8}, \mathrm{D}-\mathrm{Trp}^{22}, \mathrm{Tyr}^{25}\right]$-somatostatin $28 \quad\left({ }^{125} \mathrm{I}-\right.$ [LTT]-SS-28), known to label somatostatin receptors specifically. ${ }^{18}{ }^{19}\left[\mathrm{Tyr}^{3}\right]$-octreotide was iodinated, purified by high pressure liquid chromatography, and characterised in standard binding assays as described previously. ${ }^{18}$ LTTSS-28 was iodinated and purified by Anawa (Wangen, Switzerland). Specific activity was $2000 \mathrm{Ci} / \mathrm{mmol}$. Sections were incubated for two hours at ambient temperature in the presence of $65 \mathrm{pM}$ iodinated ligand. ${ }^{4}$ The incubation solution was $170 \mathrm{mmol} / \mathrm{l}$ Tris- $\mathrm{HCl}$ buffer
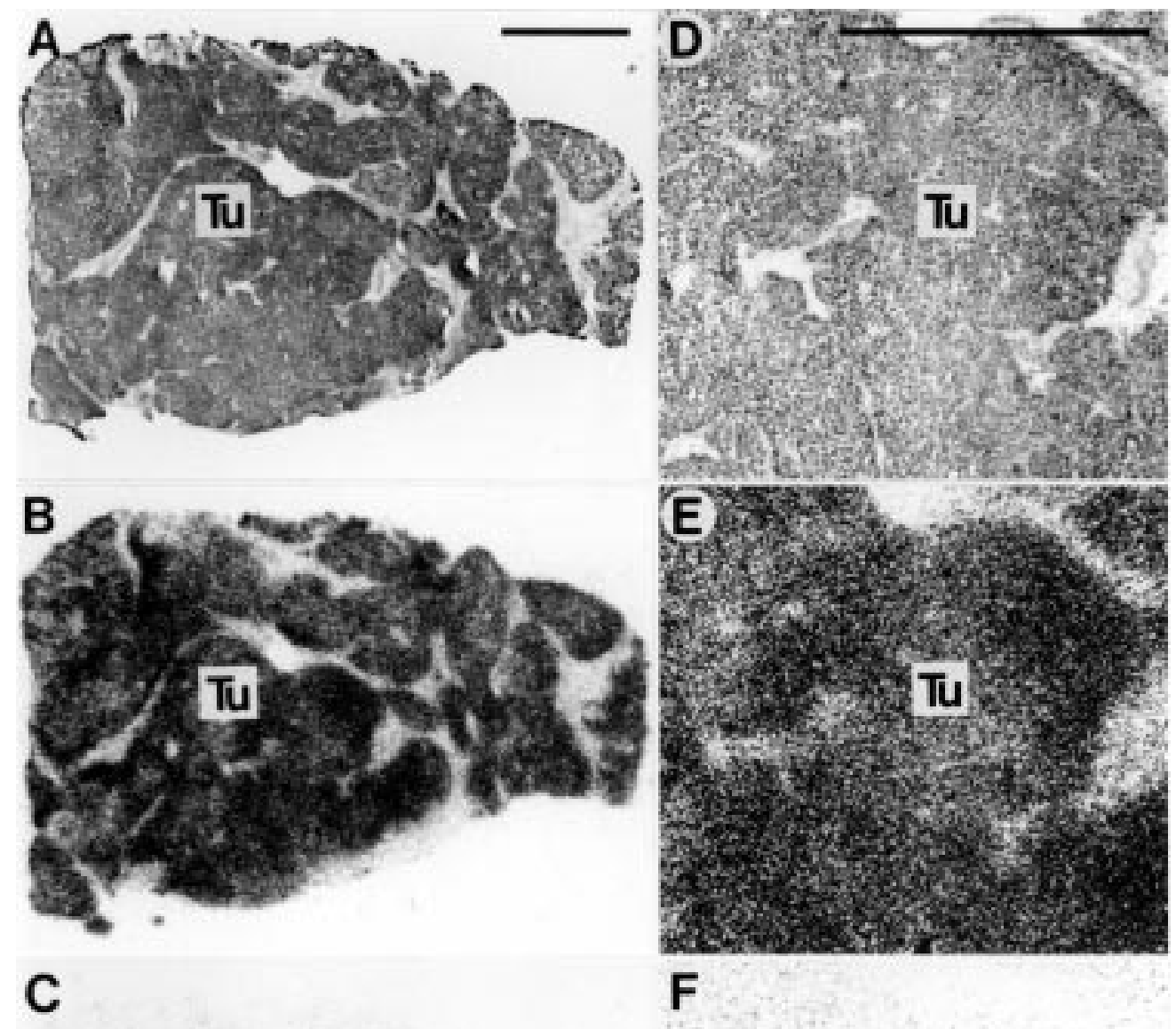

Figure 1 Somatostatin receptors in hepatocellular carcinoma. $(A, D)$ Haematoxylin and eosin stained sections. $D$ is an area of $A$ at higher magnification. $(B, E)$ Autoradiograms showing total binding of ${ }^{125}$ I-labelled [Tyr $\left.{ }^{3}\right]$-octreotide.

Homogenous labelling of tumour (Tu) tissue can be seen clearly. (C,F) Autoradiograms showing non-specific binding of ${ }^{125}$ I-labelled [Tyr $]$-octreotide (in the presence of $10^{-6} \mathrm{M}$ unlabelled octreotide). Bars $=1 \mathrm{~mm}$. 


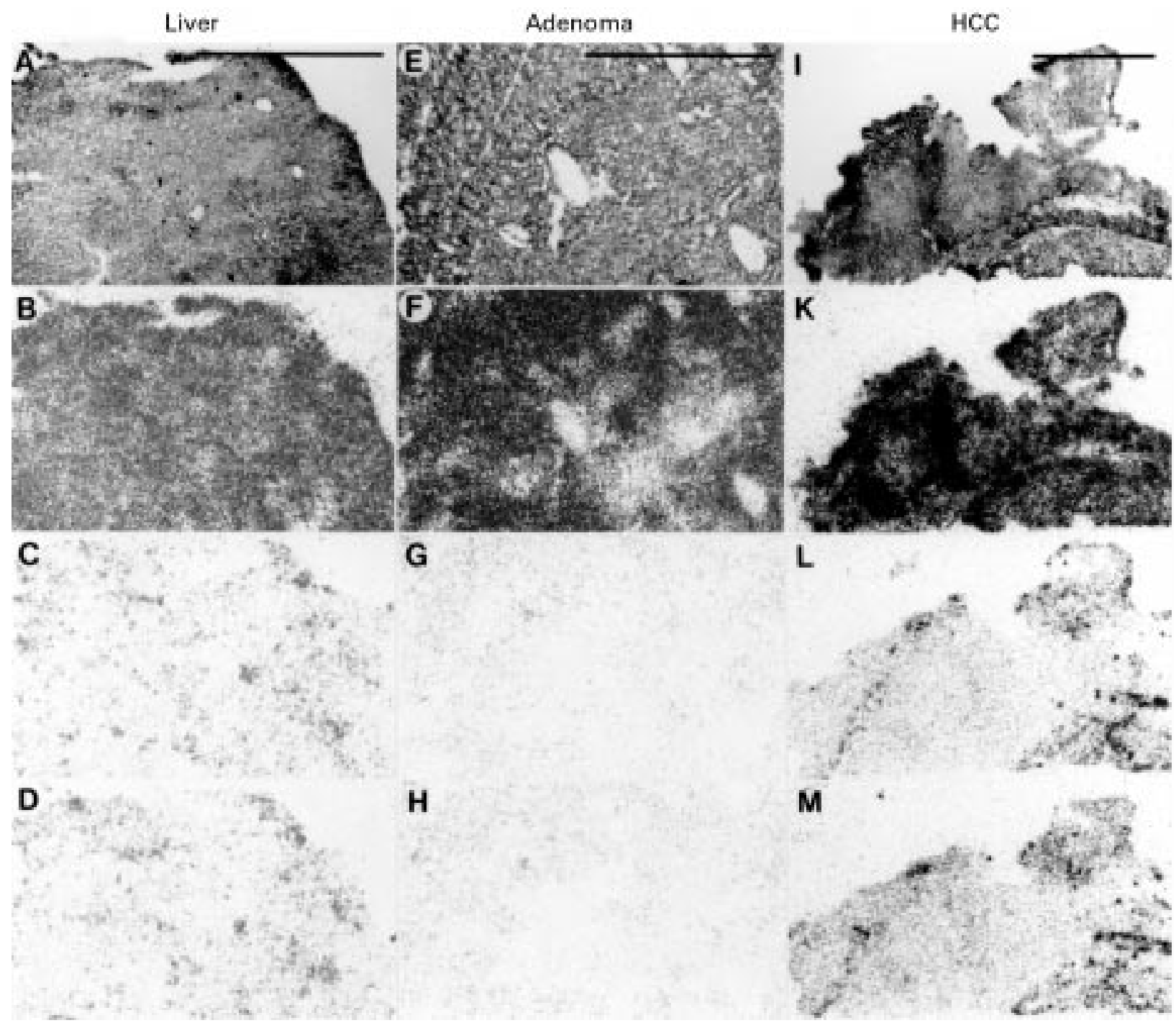

Figure 2 Vasoactive intestinal peptide (VIP) receptors in liver $(A-D)$, hepatic adenoma $(E-H)$, and hepatocellular carcinoma $(H C C)(I-M)$. (A,E,I) haematoxylin and eosin stained sections. (B,F,K) Autoradiograms showing total binding of ${ }^{125} I-V I P$. $(C, G, L)$ Autoradiograms showing a discrete residual non-specific binding of ${ }^{125} \mathrm{I}-V I P$ in the presence of $20 \mathrm{nM}$ unlabelled VIP. (D,H,M) Autoradiograms showing the same residual non-specific binding of ${ }_{125} \mathrm{I}-V I P$ in the presence of $20 \mathrm{nM}$ pituitary adenylate cyclase activating peptide (PACAP) 27. All three tissues expressed VIP receptors. Bars $=1 \mathrm{~mm}$.

(pH 8.2) containing $1 \%$ bovine serum albumin (BSA), bacitracin $(40 \mu \mathrm{g} / \mathrm{ml})$, and $\mathrm{MgCl}_{2}(10$ $\mathrm{mmol} / \mathrm{l})$ to inhibit endogenous proteases. Nonspecific binding was checked by adding 1 $\mu \mathrm{mol} / 1$ solution of unlabelled [ $\left.\mathrm{Tyr}^{3}\right]$-octreotide or somatostatin 28 (Bachem, Bubendorf, Switzerland). Incubated sections were washed twice for five minutes in cold incubation buffer containing $0.25 \% \mathrm{BSA}$, then in buffer alone, and dried quickly. Finally, the sections were apposed to ${ }^{3} \mathrm{H}$-Hyperfilms (Amersham, Little Chalfont, UK) and exposed for one week in $x$ ray cassettes. Adjacent sections from all samples were tested with ${ }^{125} \mathrm{I}-\left[\mathrm{Tyr}^{3}\right]$-octreotide and with the somatostatin 28 radioligand ${ }^{125} \mathrm{I}$-[LTT]-SS-28, to evaluate whether the same tissue elements were identified by both ligands. In selected cases, displacement experiments were performed in successive tissue sections using increasing concentrations of various biologically active (somatostatin 14, somatostatin 28 , or [ $\left.\mathrm{Tyr}^{3}\right]$-octreotide) or biologically inactive (somatostatin 28(1-12)) somatostatin analogues. The autoradiograms were quanti- fied using a computer assisted image processing system, as described previously. ${ }^{4}$ Tissue standards for iodinated compounds (Amersham) were used for this purpose.

\section{VIP RECEPTOR AUTORADIOGRAPHY}

${ }^{125} \mathrm{I}$-labelled VIP (2000 Ci/mmol; Anawa) was used as the radioligand, as described previously. ${ }^{5}$ The slide mounted tissue sections were allowed to reach room temperature and then incubated for 90 minutes in a solution of $50 \mathrm{mM}$ Tris- $\mathrm{HCl}, \mathrm{pH}$ 7.4, containing BSA (2\%), EGTA $(2 \mathrm{mM})$, bacitracin $(0.1 \mathrm{mM})$, and $\mathrm{MgCl}_{2}(5 \mathrm{mM})$ to inhibit endogenous proteases, in the presence of $30 \mathrm{pM}{ }^{125} \mathrm{I}-\mathrm{VIP}$, at room temperature, as described previously. ${ }^{5}$ After this incubation, the slides were washed twice in ice cold $50 \mathrm{mM}$ Tris- $\mathrm{HCl}, \mathrm{pH} 7.4$ containing $0.25 \% \mathrm{BSA}$, then in buffer alone, and quickly dried under a stream of cold air. The sections were subsequently exposed to a ${ }^{3} \mathrm{H}$-Hyperfilm for one week. In selected cases, displacement experiments using successive serial sections of a tumour were performed 


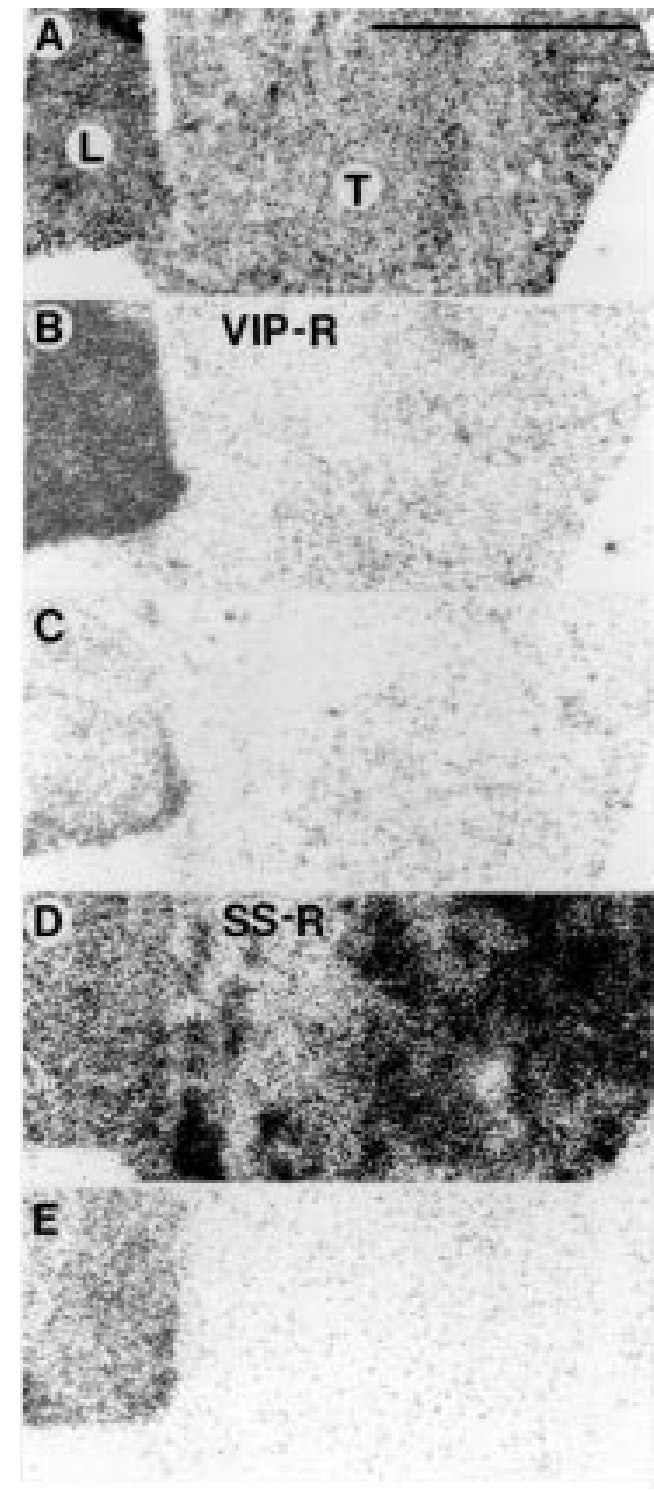

Figure 3 Vasoactive intestinal peptide (VIP) and somatostatin receptors in a surgically resected sample of hepatocellular carcinoma (HCC) containing tumour and liver tissue. (A) Haematoxylin and eosin stained section showing HCC (T) and adjacent liver $(L)$. (B)

Autoradiogram showing total binding of ${ }^{125} I-V I P$ in the section shown in A. (C) Autoradiogram showing non-specific binding of ${ }^{125} I-V I P$. (D) Autoradiogram showing total binding of ${ }^{125}$ I-[Tyr $\left.{ }^{3}\right]$-octreotide

(corresponding to a section different but consecutive to that in A). (E) Autoradiogram showing non-specific binding of ${ }_{125}$ I-[Tyr $\left.{ }^{3}\right]$-octreotide. VIP receptors were identified in liver tissue but not in HCC (B); somatostatin receptors were identified in HCC but not in liver (D). Liver had high non-specific binding for ${ }^{125} I-\left[T y r^{3}\right]$-octreotide (seen in E). Bar $=1 \mathrm{~mm}$.

with increasing concentrations of unlabelled VIP, pituitary adenylate cyclase activating peptide 27 (PACAP-27), and somatostatin 14. Moreover, in most VIP receptor positive tumours, the VIP1 selective analogue $\left[\mathrm{K}^{15}, \mathrm{R}^{16}\right.$, $\left.\mathrm{L}^{27}\right] \mathrm{VIP}(1-7) / \mathrm{GRF}(8-27)$ was used to differentiate VIP1 and VIP2 receptor subtypes. ${ }^{20}$ In order to estimate non-specific binding, paired serial sections were incubated as described earlier, except that $1 \mu \mathrm{M}$ VIP (Bachem, Bubendorf, Switzerland) was added to the incubation medium. Non-specific binding was higher for ${ }^{125}$ I-VIP (mean values $17 \%$ of total binding for liver and $27 \%$ for HCC) than for ${ }^{125} \mathrm{I}^{-\mathrm{Tyr}^{3}}$ octreotide (mean values $3 \%$ in HCC) or ${ }^{125}$ I-Bolton-Hunter substance P $\left({ }^{125} \mathrm{I}\right.$-BHSP) (mean values $7 \%$ in vessels).

In addition, in all VIP receptor positive tumours and 10 VIP receptor negative tumours, receptor autoradiography using ${ }^{125} \mathrm{I}-\mathrm{N}-$ acetyl-PACAP-27 was performed as reported previously. ${ }^{21}$ Displacement of the radioligand was measured with increasing concentrations of PACAP-27 and VIP in order to differentiate between PACAP I and VIP/PACAP II receptors. The autoradiograms were quantified using a computer assisted image processing system, as described above.

SUBSTANCE P RECEPTOR AUTORADIOGRAPHY The radioligand used was ${ }^{125} \mathrm{I}-\mathrm{BHSP}(2000$ $\mathrm{Ci} / \mathrm{mmol}$; Anawa) as described previously. ${ }^{7}$ The sections were incubated for two hours in a solution of $50 \mathrm{mM}$ Tris- $\mathrm{HCl}(\mathrm{pH} 7.4)$ containing BSA (0.02\%), chymostatin (2 $\mathrm{mg} / \mathrm{l})$, leupeptin (4 mg/l), bacitracin (40 mg/l), $\mathrm{MnCl}_{2}$ (5 $\mathrm{mM}$ ), and $50 \mathrm{pM}{ }^{125} \mathrm{I}-\mathrm{BHSP}$, at room temperature. To estimate non-specific binding, paired serial sections were incubated as described above, except that $1 \mu \mathrm{M}$ substance $\mathrm{P}$ (Bachem, Bubendorf, Switzerland) was added to the incubation medium. After this incubation, the slides were rinsed with four washes of 30 seconds each in ice cold $50 \mathrm{mM}$ Tris- $\mathrm{HCl}$ ( $\mathrm{pH} 7.4$ ), dipped in ice cold distilled water, and then quickly dried in a refrigerator under a stream of cold air. The sections were subsequently exposed to a ${ }^{3} \mathrm{H}$-Hyperfilm for one week. In addition to substance $P$, the neuroki$\operatorname{nin} 1(\mathrm{NK} 1)$ selective agonist $\left[\operatorname{Sar}^{9}, \operatorname{Met}\left(\mathrm{O}_{2}\right)^{11}\right]-$ substance $\mathrm{P}$ was used, as well as the NK2 selective agonist $\left[\mathrm{Nle}^{10}\right]$-neurokinin $\mathrm{A}_{4-10}$, and the NK3 selective agonist senktide (Bachem).

CCK AND NEUROTENSIN RECEPTOR AUTORADIOGRAPHY

CCK receptor autoradiography was performed as described previously, ${ }^{62}$ using the CCK analogue ${ }^{125} \mathrm{I}-\mathrm{D}-\mathrm{Tyr}-\mathrm{Gly}-\mathrm{Asp}-\mathrm{Tyr}\left(\mathrm{SO}_{3} \mathrm{H}\right)-\mathrm{Nle}-$ Gly-Trp-Nle-Asp-Phe-amide as radioligand. Neurotensin receptor autoradiography was performed as reported previously, ${ }^{9}$ using ${ }^{125} \mathrm{I}-$ $\left[\mathrm{Tyr}^{3}\right]$-neurotensin as the radioligand.

\section{Results}

Table 1 summarises the receptor characteristics of the 59 HCC and two liver adenomas. It can be seen that somatostatin receptors and VIP receptors are frequently expressed in these tumours. Indeed, $41 \%$ of the HCC were somatostatin receptor positive and $47 \%$ were VIP receptor positive. No obvious correlation was seen between receptor status and the type and grade of the tumours. In a few cases, a heterogeneous distribution was observed: in one case, somatostatin receptors were present in the G2 part but absent in the G3 part of the tumour; in another case, VIP receptors were present in the pseudoglandular but not in the trabecular part (table 1). Furthermore, it should be noticed that VIP receptors were also identified in one hepatic adenoma, as well as in all samples containing non-neoplastic liver tissue - that is, in 


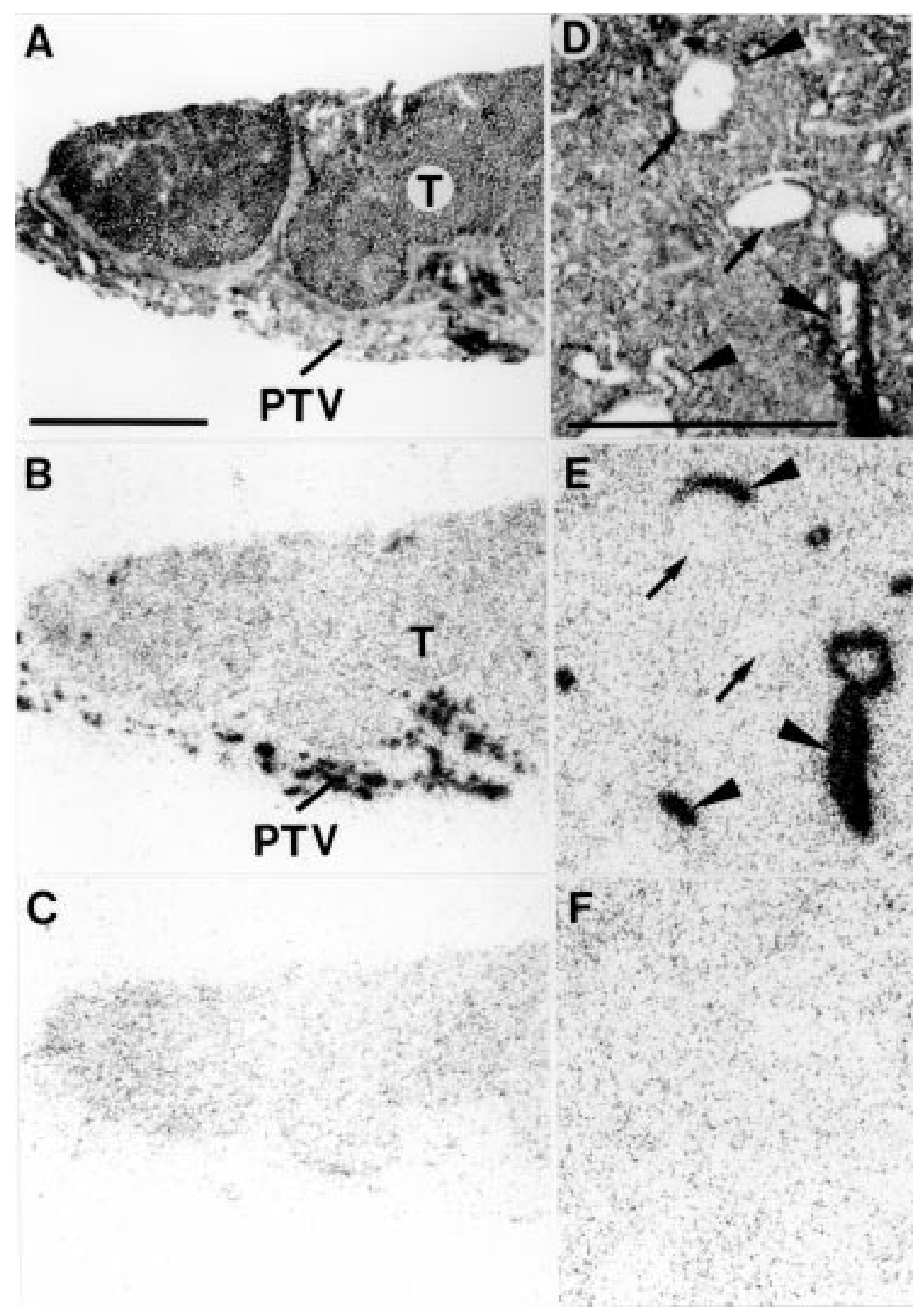

Figure 4 Substance P receptors in hepatocellular carcinoma $(H C C)(A-C)$ and a hepatic adenoma $(D-F) .(A, D)$ Haematoxylin and eosin stained sections. In $A$, the tumour $(T)$ is surrounded by stroma containing peritumorous vessels (PTV). In D, the adenoma contains arteries (arrowheads) and veins (arrows). (B,E) Autoradiograms showing total binding of ${ }^{125} I-B H S P$ (Bolton-Hunter substance P). (C,F) Autoradiograms showing non-specific binding of ${ }^{125} I-B H S P$ (in the presence of $10^{-6} \mathrm{M}$ substance $P$ ). Peritumorous vessels are strongly labelled in $B$. Intratumorous arteries are strongly labelled in $E$, whereas veins are not. In both cases, the tumours are substance P receptor negative. Bars $=1 \mathrm{~mm}$.

liver located in the immediate surroundings of HCC or of metastases of neuroendocrine tumours, as well as in two pieces of normal liver obtained separately. The individual receptor density values reported in table 1 showed a large variability among the tested tumours, both for somatostatin receptors and for VIP receptors. The somatostatin receptor density was, however, low in approximately half of the receptor positive cases (table 1 ).
Table 2 shows that the somatostatin receptor density in HCC was low compared with the much higher receptor density in liver metastases from neuroendocrine tumours. In general, the density of the VIP receptors in the receptor positive HCC was moderate, in comparison with the high density found in the liver (table 2). Twelve tumours of this series were concomitantly somatostatin receptor and VIP receptor positive (table 1). Only three of the 59 


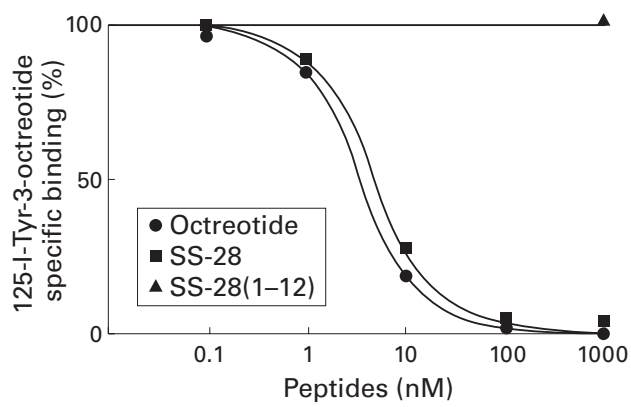

Figure 5 Displacement curve of ${ }^{125}$ I-labelled

[Tyr ${ }^{3}$ ]-octreotide in tissue sections from hepatocellular carcinoma. Tissue sections were incubated with 65 pM

${ }^{125}$ I-labelled [Tyr ${ }^{3}$ ]-octreotide and increasing concentrations of unlabelled octreotide, somatostatin (SS) 28 , or $1000 \mathrm{nM}$ somatostatin 28(1-12). Each point represents the optical density of binding in a large, homogeneously labelled area of tumour tissue $(n=4)$. Non-specific binding was subtracted from all values.

tested HCC were substance $\mathrm{P}$ receptor positive; however, a majority of the cases expressed substance $\mathrm{P}$ receptors, often at high density, in the vessels present in the tumour samples. The receptor expressing vessels were arteries in most cases, located in the peritumorous area (portal fields) and intratumorally (best seen in the two liver adenomas). Substance $P$ receptors were usually identified in vessels larger than $100 \mu \mathrm{m}$. The tested tumour samples were usually small and did not always contain such large sized vessels, explaining why substance $P$ positive vessels were not identified in all the cases listed in table 1 . In the normal liver tissues, only faint labelling of vascular structures in the portal fields was observed; again, the very small size of these vessels may have accounted for these results.

No CCK or neurotensin receptors could be identified with receptor autoradiography in any of these tumours. Figure 1 shows an example of a somatostatin receptor positive HCC, performed with in vitro receptor autoradiography and showing homogeneous distribution of the receptors. Figure 2 shows the presence of VIP receptors in a normal liver, hepatic adenoma, and HCC. In all cases, complete displacement of the radioligand is observed with $20 \mathrm{nM}$ of either VIP or PACAP-27. Figure 3 shows an HCC containing adjacent liver tissue: the tumour expresses somatostatin receptors but not VIP receptors, whereas the liver expresses VIP receptors but not somatostatin receptors. Figure 4 shows an HCC without tumorous substance $\mathrm{P}$ receptors but with the surrounding peritumorous vessels expressing a high density of substance $\mathrm{P}$ receptors. Moreover, intratumorous arteries expressing substance $P$ receptors are shown in the hepatic adenoma (fig 4).

The various receptors were characterised by displacement experiments using various analogues. Figure 5 shows a typical displacement curve of iodinated [ $\left.\mathrm{Tyr}^{3}\right]$-octreotide in HCC: both octreotide and somatostatin 28 displaced the radioligand completely and with high affinity ( $\mathrm{IC}_{50} 3.4 \mathrm{nM}$ and $4.2 \mathrm{nM}$ respectively), whereas the biologically inactive somatostatin 28(1-12) did not displace it $\left(\mathrm{IC}_{50}>1000 \mathrm{nM}\right)$. Although the somatostatin receptor positive tumours could be labelled with either ${ }^{125} \mathrm{I}-$

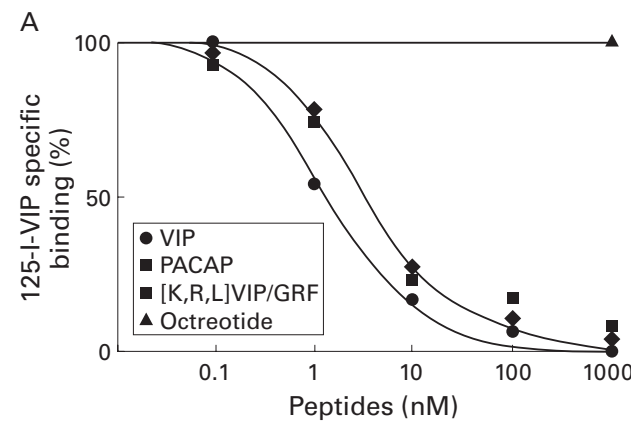

B

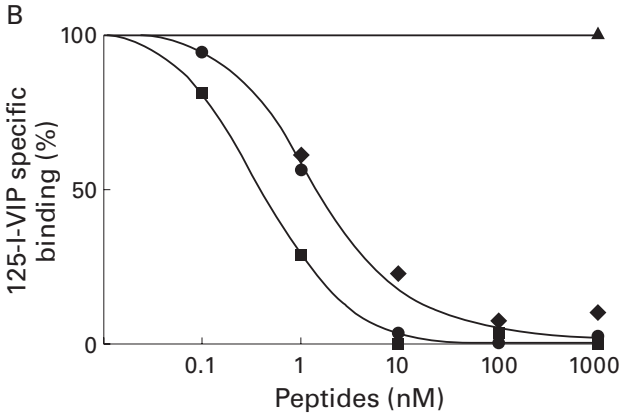

Figure 6 Displacement curves of specific ${ }^{125}$ I-vasoactive intestinal peptide (VIP) binding to tissue sections from $(A)$ liver and $(B)$ hepatocellular carcinoma. Tissue sections were incubated with $30 \mathrm{pM}{ }^{125} \mathrm{I}-V I P$ and increasing concentrations of unlabelled VIP, pituitary adenylate cyclase activating peptide (PACAP) 27, $\left[K^{15}, R^{16}, L^{17}\right]$

$V I P(1-7) / G R F(8-27)$, or 1000 nM of octreotide. Each point represents the optical density of binding in a large, homogeneously labelled area of liver or tumour tissue in one section. Non-specific binding was subtracted from all values.

[Tyr ${ }^{3}$ ]-octreotide or ${ }^{125}$ I-[LTT]-SS-28, labelling was more intense with the stable ${ }^{125} \mathrm{I}-$ $\left[\mathrm{Tyr}^{3}\right]$-octreotide radioligand. Figure 6 shows a displacement curve using iodinated VIP as radioligand: in both normal liver and HCC, VIP and PACAP-27 displaced the radioligand completely and with high affinities $\left(\mathrm{IC}_{50}\right.$ values 1.3 and $3.2 \mathrm{nM}$ for liver, 1.7 and $0.4 \mathrm{nM}$ for HCC, respectively), whereas somatostatin was ineffective $\left(\mathrm{IC}_{50}>1000 \mathrm{nM}\right)$.

In the liver tissues and in the tumours expressing the VIP/PACAP II receptors, the VIP1 selective analogue $\left[\mathrm{K}^{15}, \mathrm{R}^{16}, \mathrm{~L}^{17}\right] \mathrm{VIP}(1-$ 7)/GRF(8-27) could displace the radioligand with high affinity $\left(\mathrm{IC}_{50} 3.2\right.$ and $1.7 \mathrm{nM}$ respectively), suggesting the presence of VIP1 rather than VIP2 receptors (fig 6 and table 1). Furthermore, all VIP receptor positive tumours were also investigated with the iodinated $\mathrm{N}$-acetyl-PACAP-27 ligand. ${ }^{21}$ In all but one case, PACAP-27 and VIP displaced the radioligand in the same high affinity range, suggesting the presence of VIP/PACAP II receptors. Figure 7 shows an example of a displacement curve in HCC and normal liver, indicating the presence of VIP/PACAP II receptors $\left(\mathrm{IC}_{50} 0.9\right.$ and $0.2 \mathrm{nM}$ in HCC, 1.3 and $0.4 \mathrm{nM}$ in liver, for PACAP and VIP respectively). In one tumour, the iodinated PACAP ligand was displaced completely by $20 \mathrm{nM}$ PACAP-27 but not by VIP, suggesting the predominance of PACAP I receptors in this case (table 1). Among 10 VIP receptor negative cases tested with iodinated PACAP, one case revealed the presence of a low density of PACAP I receptors 

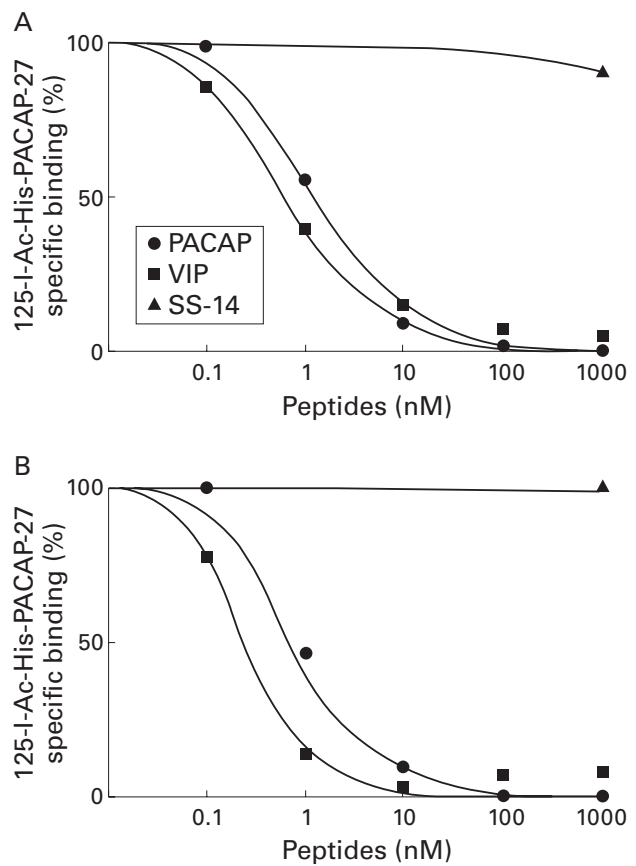

Figure 7 Displacement curves of specific

${ }^{125} I-N$-acetyl-pituitary adenylate cyclase activating peptide $(P A C A P) 27$ binding to tissue sections from $(A)$ liver and (B) hepatocellular carcinoma. Tissue sections were incubated with $30 p M^{125} I-N$-acetyl-PACAP-27 and increasing concentrations of unlabelled PACAP-27, vasoactive intestinal peptide (VIP), or $1000 \mathrm{nM}$ of somatostatin. Each point represents the optical density of binding in a large, homogeneously labelled area of liver or tumour tissue in one section. Non-specific binding was subtracted from all values.

(table 1). Displacement curves in peritumourous tissue containing substance $\mathrm{P}$ receptor positive vessels showed high affinity displacement of ${ }^{125} \mathrm{I}$-BHSP by substance $\mathrm{P}$ and the NK1 selective ligand $\left[\operatorname{Sar}^{9}, \operatorname{Met}\left(\mathrm{O}_{2}\right)^{11}\right]-$ substance $\mathrm{P}\left(\mathrm{IC}_{50} 0.9\right.$ and $2.8 \mathrm{nM}$ respectively) but not by the NK2 selective agonist $\mathrm{Nle}^{10}$ neurokinin $\mathrm{A}_{4-10}$ or the $\mathrm{NK} 3$ selective agonist senktide $\left(\mathrm{IC}_{50}>1000 \mathrm{nM}\right)$.

\section{Discussion}

This study is the first evaluation of regulatory peptide receptor expression in human HCC. The results show that somatostatin receptors and VIP receptors are frequently expressed in these tumours. As somatostatin receptors are not expressed by the human liver, the presence of somatostatin receptors in HCC may be regarded as an overexpression of receptors in these tumours. However, it should be noted that the somatostatin receptor density in these tumours is considerably lower than the receptor density found, for instance, in liver metastases of neuroendocrine tumours. All somatostatin receptor positive HCC could be labelled optimally with iodinated [ $\left.\mathrm{Tyr}^{3}\right]-$ octreotide; in displacement experiments, unlabelled octreotide was shown to bind with high affinity, suggesting that the predominant receptor subtype was sst2.

As VIP receptors are expressed in large amounts by the human liver, it is not surprising that some HCC also express VIP receptors. It is perhaps more remarkable that some of the HCC are completely lacking VIP receptors and that the others express a lower receptor density than the adjacent liver tissue, suggesting that these VIP receptors may have been lost or downregulated during neoplastic transformation. The density of VIP receptors in HCC is variable but is usually more than four times lower than in normal liver tissue.

VIP/PACAP receptors can be divided into several receptor subtypes: receptors with high affinity for VIP and for PACAP (VIP/PACAP II receptors), which can be further subdivided into VIP1 and VIP2 subtypes, and receptors with high affinity for PACAP but not for VIP (PACAP I receptors). The receptor subtypes involved in the tested liver tumours as well as in the adjacent normal human liver are predominantly VIP1/PACAP II receptors, as shown by the high affinity of VIP, PACAP-27, or a VIP1 selective analogue in displacement experiments. Primary liver tumours seem, therefore, to express the same VIP receptor subtype as their non-malignant tissue of origin. Only two of the tested tumours overexpressed the PACAP I receptor, characterised by low affinity for VIP. The somatostatin receptor expression does not seem to correlate with that of the VIP receptor and neither VIP nor somatostatin receptor expression seems to correlate with any of the histopathological parameters such as tumour type and grade.

Receptors for substance P, CCK, gastrin, and neurotensin do not seem to play a major role in HCC, although it was shown previously that fibrolamellar carcinomas of the liver can, for instance, secrete neurotensin..$^{23} \mathrm{~A}$ special case may be the presence of substance P receptors in the intratumorous and peritumorous vessels of these tumours, particularly in vessels exhibiting a diameter of more than $100 \mu \mathrm{m}$ and probably representing tumour feeding arteries. As only a faint labelling of vascular structures in normal liver tissue was noted, tumour angiogenesis may be associated with upregulation of this receptor. A potential pathophysiological role for these vascular receptors, already suggested previously in relation with other tumour types, ${ }^{7}$ is to regulate the tumour blood flow. The use of potent substance $\mathrm{P}$ analogues may, therefore, be of clinical interest.

Based on our in vitro results, there are a number of potential clinical implications linked with the somatostatin and VIP receptor expression in HCC. As a diagnostic tool, it may be possible to visualise somatostatin receptor positive HCC and their metastases by performing in vivo receptor scintigraphy of the tumours. The intensity of the signal, though, should not be expected to be as strong as for neuroendocrine tumour metastases, due to the lower receptor density. It may be more difficult to visualise VIP receptor positive HCC, due to the high liver background, caused by a high density of VIP receptors. A lack of a radioactive signal (a hole in the liver at the site of the HCC location) may, therefore, be expected more often than a positive signal with VIP receptor scintigraphy.

With respect to radiotherapy of somatostatin receptor positive tumours with compounds such as ${ }^{90}$ Y-labelled somatostatin, it may be 
predicted that the density of somatostatin receptors of these tumours would in many cases be too low to reach an adequate treatment dose of radioactivity at the tumour site. According to recent reports, a perhaps more promising clinical application could be the long term treatment of these HCC with the somatostatin analogue octreotide. It has been shown in rats, that octreotide can significantly inhibit the growth of residual intrahepatic or subcutaneous hepatomas, enhanced by partial hepatectomy. ${ }^{24}$ Moreover, Kouroumalis et al showed that patients with HCC treated with octreotide had a prolonged survival compared with untreated patients. ${ }^{15}$ Although the exact molecular mechanism for the successful treatment reported in the above mentioned studies is presently unknown, it is probable that the octreotide action is mediated, at least in part, by the somatostatin sst 2 receptors located in the HCC. Therefore, it will be important to perform prospective clinical trials comparing, in patients with HCC, the in vitro tumorous somatostatin receptor status with the effects of octreotide treatment, in order to know whether patients with HCC expressing somatostatin receptors and treated with octreotide will have a higher benefit from the octreotide treatment than treated patients with HCC lacking somatostatin receptors.

The authors thank Dr P Robberecht (Bruxelles) for the kind gift of $\left[K^{15}, R^{16}, L^{17}\right]$ VIP $(1-7) / G R F(8-27)$, Dr J Rivier (San Diego) for $\left[\mathrm{Leu}^{8}, \mathrm{D}-\mathrm{Trp}^{22}, \mathrm{Tyr}^{25}\right]$-somatostatin 28 , and Novartis Ltd (Basel) for $\left[\mathrm{Tyr}^{3}\right]$-octreotide.

1 Reubi JC. Neuropeptide receptors in health and disease: the molecular basis for in vivo imaging. $f \mathrm{Nucl} \mathrm{Med}$ 1995;36:1825-35.

2 Krenning EP, Kwekkeboom DJ, Pauwels S, et al. Somatostatin receptor scintigraphy. In: Nuclear Medicine Annual 1995, 1995:1-50.

3 Otte A, Mueller-Brand J, Dellas S, et al. Yttrium-90-labelled somatostatin-analogue for cancer treatment. Lancet 1998; 351:417-18.

4 Reubi JC, Kvols LK, Waser B, et al. Detection of somatostatin receptors in surgical and percutaneous needle biopsy samples of carcinoids and islet cell carcinomas. Cancer Res 1990;50:5969-77.

5 Reubi JC. In vitro identification of vasoactive intestinal peptide receptors in human tumors: implications for tumor tide receptors in human tumors: imp
imaging. $\mathcal{F}$ Nucl Med 1995;36:1846-53.
6 Reubi JC, Schaer JC, Waser B. Cholecystokinin(CCK)-A and CCK-B/gastrin receptors in human tumors. Cancer Res 1997;57:1377-86.

7 Hennig IM, Laissue JA, Horisberger U, et al. Substance P receptors in human primary neoplasms: tumoural and vascular localisation. Int f Cancer 1995;61:786-92.

8 Przedborski S, Levivier M, Cadet JL. Neurotensin receptors in human meningiomas. Ann Neurol 1991;30:650-4.

9 Reubi JC, Waser B, Friess H, et al. Neurotensin receptors: a new marker for human ductal pancreatic adenocarcinoma. Gut 1998;42:546-50.

10 Lamberts SWJ, Krenning EP, Reubi JC. The role of somatostatin and its analogs in the diagnosis and treatment of tumors. Endocr Rev 1991;12:450-82.

11 Virgolini I, Raderer M, Kurtaran A, et al. Vasoactive intestinal peptide-receptor imaging for the localization of intestinal adenocarcinomas and endocrine tumors. $N$ Engl f Med 1994;331:1116-21.

12 Behr TM, Jenner N, Radetzky S, et al. Targeting of cholecystokinin-B/gastrin receptors in vivo: preclinical and initial clinical evaluation of the diagnostic and therapeutic potential of radiolabelled gastrin. Eur F Nucl Med 1998;25: potential

13 Zimmermann A. Tumors of the liver-pathological aspects. In: LH Blumgart, ed. Surgery of the liver and biliary tract. Edinburgh: Churchill Livingstone, 1994:1277-323.

14 Zhao M, Laissue JA, Zimmermann A. "Neuroendocrine" differentiation in hepatocellular carcinomas (HCCs): immunohistochemical reactivity is related to distinct tumor cell types, but not to tumor grade. Histol Histopathol 1993; 8:617-26.

15 Kouroumalis E, Skordilis P, Thermos K, et al. Treatment of hepatocellular carcinoma with octreotide: a randomised controlled study. Gut 1998;42:442-7.

16 Gibson JB, Sobin LH. Histological typing of tumours of the liver, biliary tract and pancreas. In: International histological classification of tumours, 20. Geneva: World Health Organisation, 1978.

17 Edmondson HA, Steiner PE. Primary carcinoma of the liver. A study of 100 cases among 48900 necropsies. Cancer 1954;7:462-503.

18 Reubi JC, Perrin MH, Rivier JE, et al. High affinity binding sites for a somatostatin-28 analog in rat brain. Life Sci 1981;28:2191-8.

19 Reubi JC. New specific radioligand for one subpopulation of brain somatostatin receptors. Life Sci 1985;36:1829-36.

20 Gourlet P, Vandermeers A, Vertongen P, et al. Development of high affinity selective VIP1 receptor agonists. Peptides 1997; 18:1539-45.

21 Reubi JC, Waser B, Laederach U, et al. Pituitary adenylate cyclase activating polypeptide (PACAP) I and PACAP II receptors in human tumors: in vitro binding of DTPAlinked PACAP analogs. Eur F Nucl Med 1997;24:1058.

22 Reubi JC, Waser B, Läderach U, et al. Localization of cholecystokinin A and cholecystokinin B/gastrin receptors in the human stomach and gallbladder. Gastroenterology 1997; 112:1197-205.

23 Collier NR, Weinbren K, Bloom SR, et al. Neurotensin secretion by fibrolamellar carcinoma of the liver. Lancet 1984;i:538-40.

24 Schindel DT, Grosfeld JL. Hepatic resection enhances growth of residual intrahepatic and subcutaneous hepatoma, which is inhibited by octreotide. I Pediatr Surg 1997;32:995-8. 